\title{
SYNTHESIS AND CHARACTERIZATION $\mathrm{OF} \mathrm{LiFePO}_{4} / \mathrm{PPy} / \mathrm{CLAY}$ COMPOSITE AS CATHODE MATERIAL FOR Li-ION BATTERY
}

\author{
Indra Gunawan, Yustinus P., Sudaryanto and Jadigia Ginting \\ Center of Science and Technology for Advanced Materials - BATAN \\ Kawasan Puspiptek, Serpong 15413, Tangerang Selatan \\ Email :irgun.ig@gmail.com
}

Received: 10 October 2019

Revised: 10 January 2019

Accepted: 17 January 2020

\begin{abstract}
SYNTHESIS AND CHARACTERIZATION OF LiFePO/PPy/CLAY COMPOSITE AS CATHODE MATERIAL FOR Li-ION BATTERY. Conductor polymers have been used previously as a conducting agent or carbon source in various sol-gel and solid state methods to increase the conductivity of $\mathrm{LiFePO}_{4}$. The composite of $\mathrm{LiFePO}_{4} / \mathrm{PPy} /$ Clay were synthesized by mixing $\mathrm{LiFePO}_{4}$ and clay with a Ppy solution. The characterizations were done by using X-Ray Diffractometer (XRD), Scanning Electron Microscope (SEM) and LCR meter respectively. From XRD analysis it could be deduced that $\mathrm{LiFePO}_{4}$ has an ordered olivine structure with a Pnma space group. The SEM images provide clear evidence that small crystal particles of $\mathrm{LiFePO}_{4}$ either coat the surface of the clay particles or lie among them. These $\mathrm{LiFePO}_{4}$ particles have a small particle size $(100-500 \mathrm{~nm})$. With the increasing of $\mathrm{LiFePO}_{4}$ content, these small crystal particles at the surface or among the clay particles are increased. Increasing the PPy content to increase the conductivity of the material obtained. With the addition of clay from 5 to $10 \mathrm{wt}$. \%, the DC conductivity of the blends is clearly observed to increase up to three orders of magnitude.
\end{abstract}

Keywords: $\mathrm{LiFePO}_{4}$, Clay, Composites, Li-Ion battery

\begin{abstract}
ABSTRAK
SINTESIS DAN KARAKTERISASI KOMPOSIT LiFePO/PPy/CLAY SEBAGAI BAHAN KATODE UNTUK BATTERAY Li-ION. Polimer konduktor PPy telah digunakan sebagai bahan penghantar atau sumber karbon dalam berbagai metode sol-gel dan reaksi padatan untuk meningkatkan konduktivitas $\mathrm{LiFePO}_{4}$. Komposit $\mathrm{LiFePO}_{4} / \mathrm{PPy} /$ Clay disintesis dengan mencampurkan $\mathrm{LiFePO}_{4}$ dan tanah liat dengan larutan Ppy. Karakterisasi dilakukan dengan menggunakan X-Ray Diffractometer (XRD), Scanning Electron Microscope (SEM) dan LCR meter. Dari analisis XRD dapat disimpulkan bahwa $\mathrm{LiFePO}_{4}$ memiliki struktur olivin yang bersesuaian dengan grup ruang Pnma. Gambar SEM memberikan gambaran bahwa partikel kristal dengan ukuran kecil $\mathrm{LiFePO}_{4}$ melapisi permukaan partikel tanah liat atau berada di antara mereka. Partikel $\mathrm{LiFePO}_{4}$ ini memiliki ukuran partikel kecil $(100-500 \mathrm{~nm})$. Dengan meningkatnya kandungan $\mathrm{LiFePO}_{4}$, konduktivitas partikel-partikel kristal kecil di permukaan atau di antara partikel-partikel tanah liat meningkat. Meningkatnya kandungan PPy dapat meningkatkan konduktivitas bahan yang diperoleh. Dengan penambahan tanah liat dari 5 hingga $10 \mathrm{wt}$ \% , konduktivitas DC dari campuran jelas teramati terjadi peningkatan hingga tiga orde.
\end{abstract}

Kata kunci: $\mathrm{LiFePO}_{4}$, Tanah liat, Komposit, Baterai Li-Ion

\section{INTRODUCTION}

For their promising potential to be used as power sources for electric vehicles (EVs), so far, Li-ion batteries have captured a large share of the rechargeable battery market. It is generally recognized that the battery performance strongly depends on the development of electrode materials. Recently, olivine lithium iron 
phosphate $\left(\mathrm{LiFePO}_{4}, \mathrm{LFP}\right)$ has emerged as one of the most promising cathode materials because of its low cost, safety, low toxicity, and high specific capacity of $170 \mathrm{~mA} \mathrm{~h} \mathrm{g"1}$ with a flat discharge-charge potential at $3.45 \mathrm{~V}$ vs. $\mathrm{Li} / \mathrm{Li}^{+}$owing to the $\mathrm{Fe}^{2+} / \mathrm{Fe}^{3+}$ redox couple. However, one challenging issue regarding LFP cathode is its extremely poor conductivity, which induces lower rate capability. Accordingly, the LFP cathodes cannot satisfy the required power density in Li-ion battery for end- customer needs [1]. However, intrinsic low electrical conductivity and slow $\mathrm{Li}^{+}$ion diffusion directly result in initial capacity loss and poor electrochemical performance, especially at high power applications [2].

Up to the present, many effective approaches have been proposed to solve the above problem. The approaches mainly involve $\mathrm{LiFePO}_{4}$ coating with fine electronic conductive materials like carbon, reducing particle size, and $\mathrm{LiFePO}_{4}$ doping with cations. Among the above methods, cations doping at $\mathrm{Li}$-site or Fe-site of $\mathrm{LiFePO}_{4}$ is very convenient and effective to enhance the electrochemical properties of $\mathrm{LiFePO}_{4}$. The firstprinciple calculation on $\mathrm{LiMPO}_{4}(\mathrm{M}=\mathrm{Fe}, \mathrm{Mn}, \mathrm{Co}$, and $\mathrm{Ni}$ ) reveals that the lowest Li migration energy for the nonlinear pathway along the [010] channel is curved trajectory between Li sites, and with such onedimensional pathway, long- range Li conduction may be easily blocked by Li site doping. Therefore, Fe-site doping may be a more suitable strategy to enhance the intrinsic conductivity, and now great efforts have been devoted to investigate the doping effects at $\mathrm{Fe}$-site on the physicochemical and electrochemical properties of $\mathrm{LiFePO}_{4}$. In addition, an isovalent cation (such as $\mathrm{Mg}^{2+}, \mathrm{Cu}^{2+}, \mathrm{Co}^{2+}$ and so on) would easily occupy $\mathrm{Fe}$ sites of $\mathrm{LiFePO}_{4}$, it could induce the crystal lattice distortion, provide more space for intercalation/deintercalation of $\mathrm{Li}$, and thus improve the electrochemical propertiesof $\mathrm{LiFePO}_{4}$. Although many investigations have been done in order to enhance electrochemical performance of $\mathrm{LiFePO}_{4}$, it has been rarely reported on isovalent cations co-doping at $\mathrm{Fe}$ sites of $\mathrm{LiFePO}_{4}[3]$.

Concerning the synthetic routes, various methods such as modified solid state reactions, sol gel, microwave synthesis, and hydrothermal reaction have been reported, among which the hydrothermal reaction is recognized as a promising method because of some advantages like simple synthesis process and low energy consumptions compared to high temperature firings and long firing time during the solid state reaction. The hydrothermal synthesis is a method to prepare fine particles, involves dissolution of the reagents in water, precipitation of precursors and conversion of the precursors to target material phase. It is well known that carbon as reducing agent cannot only prevent the formation of $\mathrm{Fe}^{3+}$ impurity and the agglomeration of the particles during the preparation of $\mathrm{LiFePO}_{4}$, but also increases the electronic conductivity [4].
The main limitation with respect to this $\mathrm{LiFePO}_{4}$ compound is its very poor electronic conductivity which limits the cycling capability. Several methods have been proposed to solve this problem, such as carbon coating or thin metal particle dispersion. But the amount of carbon recover the theoretical capacity $(\sim 20 \%)$ and the metal used (copper or silver) are much more expensive than the cathode material itself [5]. Precipitation of precursors and conversion of the precursors to target material phase is well known that carbon as reducing agent cannot only prevent the formation of $\mathrm{Fe}^{3+}$ impurity and the agglomeration of the particles during the preparation of $\mathrm{LiFePO}_{4}$, but also increases the electronic conductivity.

Conducting polymers have been utilized previously as conducting materials or carbon sources in various sol-gel and solid state methods to $\mathrm{LiFePO}_{4}$. However, those methods coated conducting polymers by post treatment. Pyrrole as a new efficient reducing agent for hydrothermal synthesis of $\mathrm{LiFePO}_{4}$ powders. We employ the principle of oxidative polymerization of pyrrole to reduce $\mathrm{Fe}^{3+}$ to $\mathrm{Fe}^{2+}$ and to polymerize pyrrole to polypyrrole (PPy). Therefore, $\mathrm{Fe}^{3+}$ oxidized from reactant $\mathrm{Fe}^{2+}$ by air can be efficiently reduced back to $\mathrm{Fe}^{2+}$ because the hydrothermal solution contains pyrrole. To compare with other hydrothermal syntheses, this is an in situ approach to coat PPy on $\mathrm{LiFePO}_{4}$ as the hydrothermal synthesis of $\mathrm{LiFePO}_{4}$, which is more feasible. In addition, the thickness of carbon layer may be controlled by addition of $\mathrm{Fe}^{3+}$ as a precursor of $\mathrm{LiFePO}_{4}$ and an oxidant for the polymerization of pyrrole [6].

Considering simple carbon coating or additive is excluded to obtain perfect rate performance, an electrode consisting of carbon-coated, submicron-sized crystalline $\mathrm{LiFePO}_{4}$ with $3 \mathrm{D}$ porosity is appealing since it can provide fast electronic conduction in the solid phase and ion conduction at reasonable rates in both solid and liquid phases. This has been collaborated by recent work on porous carbon monoliths, showing superior high-rate performance. In view of its facility in terms of synthesis and porous structure, the design is superior to insert subcmicron sized particles into a porous carbon matrix. Recently, CNTs providing 3D have receive a wide attention due to its most effective in reducing the resistance, and thus improving the electrochemical performance of the composite cathode [7]. Carbon coating does not change its intrinsic conductivity, but it is very effective in enhancing capacity and rate capability. Carbon black and sugar are used as main carbon sources. The electronic conductivity of $\mathrm{LiFePO}_{4} / \mathrm{Ppy} / \mathrm{Clay}$ composite prepared reached $0.1 \mathrm{~S} / \mathrm{cm}$ [10]. Adding $25 \%$ PPy in the starting materials, an improvement in its practical capacity and rate capability was seen. Carbon can control particle growth and enhance electronic conductivity, therefore, higher capacity and better rate capability can be obtained [8]. 
Clay minerals, a large family of alumino-silicate structures with a range of chemical composition, structure and surface properties, are very reactive materials due to their small grain size, large surface area, adsorption properties and chemical variability. Therefore, they are of considerable recognition in all the physical, chemical and environmental processes in soils and sediments,and frequently control them. The industrial application of clays is enormous and grows with our ability to engineer their properties and use them in the production of composite materials [9] . Zeolites/clays are microporous crystalline hydrated aluminosilicates with a net negative charge due to the presence of aluminum ions in their framework. This negative charge will balance by extra frame-work cations. Clinoptilolite, as the most abundant natural zeolite, has been widely used in research studies and its chemical composition, surface characteristics and ion exchange properties have been reported in many studies [10].

In this research paper, we report on an in-situ synthesis of $\mathrm{LiFePO}_{4} / \mathrm{PPy}$ - Clay composite electrode materials aiming to achieve homogenious micro structures and better battery behavior. PPy and Clay will increase the electronic conductivity of $\mathrm{LiFePO}_{4}$ by means of a different mechanism. The incorporation of $\mathrm{LiFePO}_{4}$ with zeolites composites in order to achieve three dimensional porous $\mathrm{LiFePO}_{4}$ architectures also to achieve fast electronic and ion conduction, while keeping an acceptable tap density.

\section{EXPERIMENTAL METHOD}

$\mathrm{LiFePO}_{4}, \mathrm{LFP}$, polypyrole,PPy and clay were purchased from Aldricth with pa degree. LFP, PPy and clay were mixed and then heat traeted at $70^{\circ} \mathrm{C}$ in the oven. The composition of LFP, PPy and clay in the mixtures was varied as follow:

Table 1. The composition of LFP, PPy and clay in the samples

\begin{tabular}{llllll}
\hline \multirow{2}{*}{ Compound } & \multicolumn{5}{c}{ Code of samples/weight \% } \\
\cline { 2 - 6 } & K1 & K2 & K3 & K4 & K5 \\
\hline LFP & 90 & 88.75 & 82.5 & 76.25 & 70 \\
Ppy & 0 & 2.5 & 10 & 17.5 & 25 \\
Clay & 10 & 8.75 & 7.5 & 6.25 & 5 \\
\hline
\end{tabular}

Crystalline phases of the samples were identified by XRD at room temperature. Shimadzu XD- 610 equipped with a $\mathrm{Cu} \mathrm{K} \alpha$ source target was utilized to record the XRD pattern of the samples. Diffraction patterns were logged with a goniometer (2è) from $10^{\circ}$ to $80^{\circ}$. The morphology of the samples was observed by means of SEM on the surface of the samples. JEOL JSM6510LA equipped with EDS was employed to observe the morphology and elemental analysis of the samples. Electrochemical characterization was carried out for the samples using a HIOKI LCR HiTESTER 3532-50 for EIS.
Impedance spectra were collected in an ambient atmosphere and temperature at an applied voltage of $1 \mathrm{~V}$ over a frequency range of $42 \mathrm{~Hz}-1 \mathrm{MHz}$. All the charactrizations equipments were located at BSBM, PSTBM, BATAN Kawasan Puspiptek Serpong, Tangerang Selatan.

\section{RESULT AND DISCUSSION}

Figure 1 represents the XRD patterns of samples, all the peaks are in accordance with the reference $\mathrm{LiFePO}_{4}$ pattern (PDF No. 40-1499). The peaks which is marked by the appearance of diffraction quite narrow, symmetrical at the $2 \theta=17^{\circ} ; 20,73^{\circ} ; 23,14^{\circ} ; 24,33^{\circ}$; $26,5^{\circ} ; 27,45^{\circ} ; 28,8^{\circ} ; 29,32^{\circ} ; 32,1^{\circ}, 35,6^{\circ} ; 36,5^{\circ} ; 38^{\circ}$; $42^{\circ} ; 44^{\circ} ; 54^{\circ}$ and $56,93^{\circ}$. All samples are identified as perfectly single-phase olivine structure indexed to orthorhombic Pnma space group, without any second phase or impurities observed, i.e. the addition of clay does not generate impurities or cause any phase transformation of the samples. $\mathrm{LiFePO}_{4}$ has an ordered olivine structure with a Pnma space group.

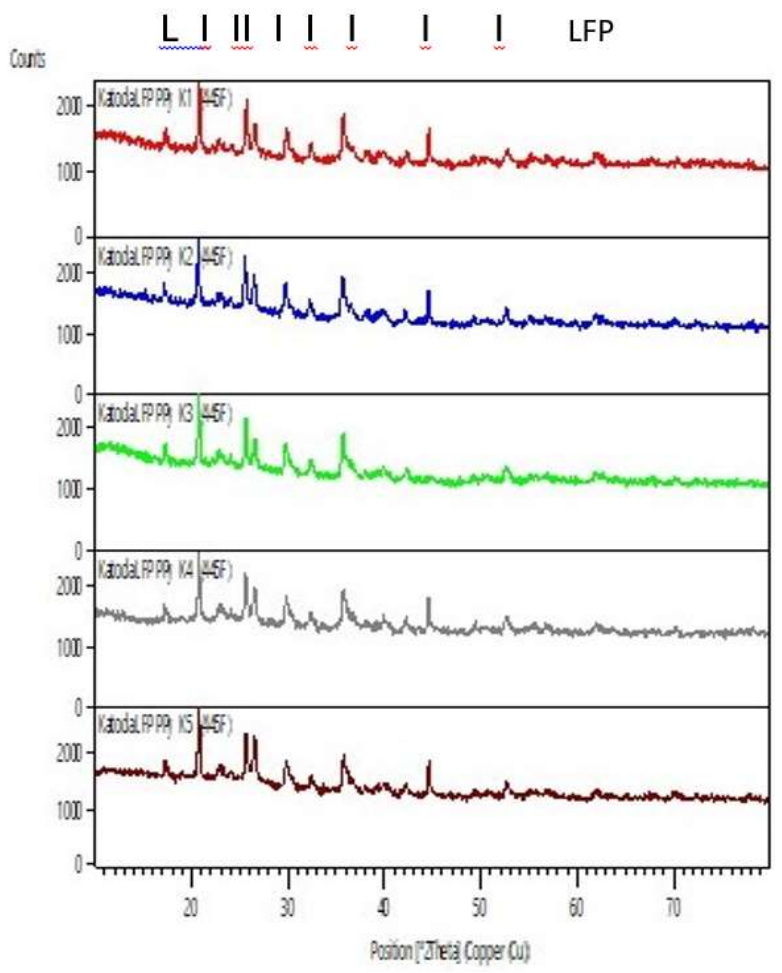

Figure 1. Represents the XRD patterns of samples

The SEM images of composites with different $\mathrm{LiFePO}_{4}$ contents are shown in Fig. 2. The images provide clear evidence that small crystal particles of $\mathrm{LiFePO}_{4}$ either coat the surface of the clay particles or lie among them. These $\mathrm{LiFePO}_{4}$ particles have a small particle size $(100-500 \mathrm{~nm})$. The smaller the particles size the better the ionic conductivity will be, because the $\mathrm{Li}$ ion can decalate easily in a short pathway, but other variables such as purity and crystallinity must be considered. With 

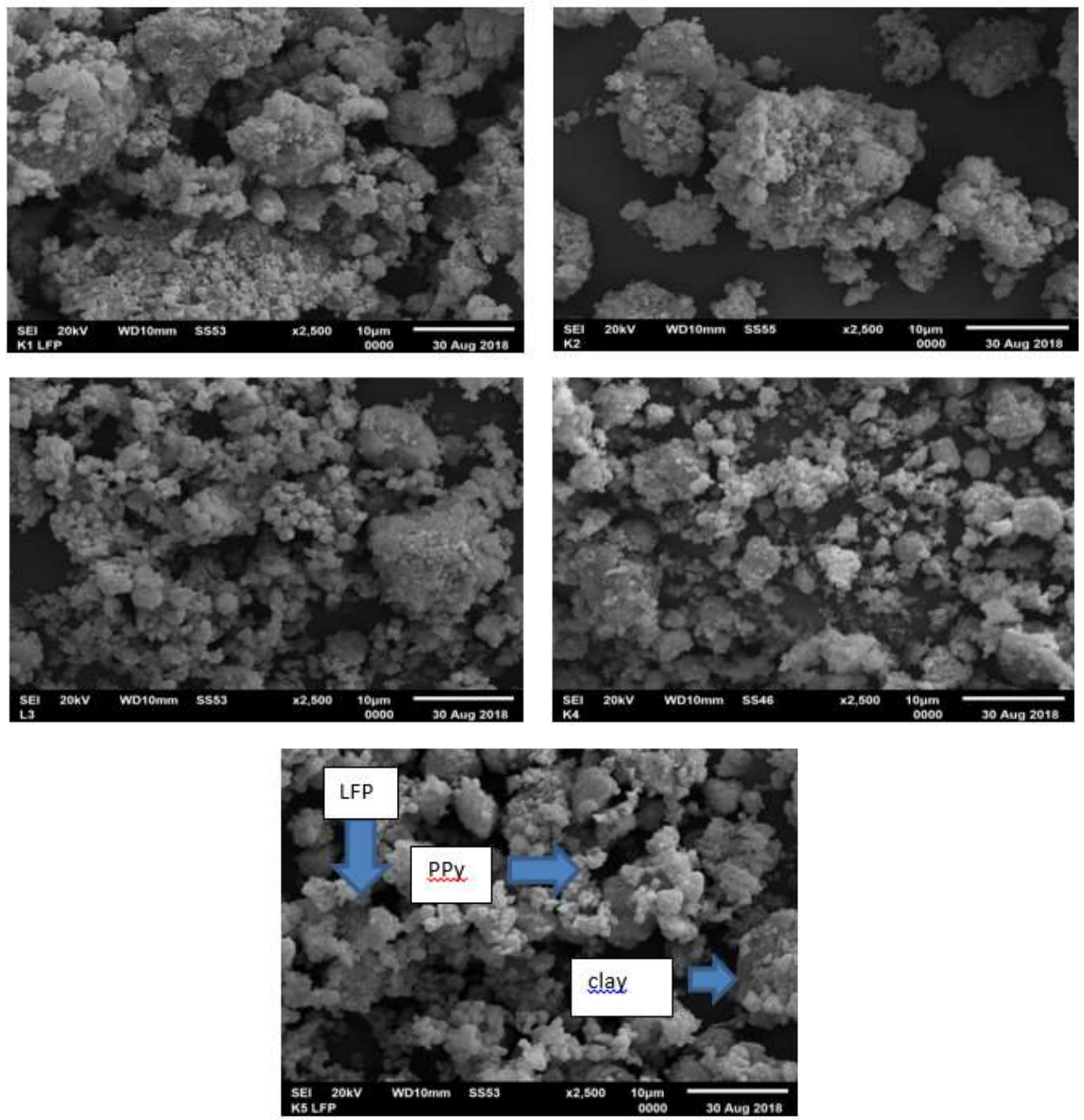

Figure 2. The SEM images of composites with different LiFePO4/Ppy/clay contents

the increasing of $\mathrm{LiFePO}_{4}$ content, these small crystal particles at the surface or among the clay particles are increased. Clay providing $3 \mathrm{D}$ porosity have most effective in reduced the resistance, and thus improving the electrochemical performance of the composite cathode. An increase in porosity decreases the active surface area, reduces the electrical path into the graphite particles and reduces the accessibility of the lithium ions into the current collector. Due to the agglomeration of the clay during the in- situ synthesis, the surfactant was added to enhance the dispersing of the clay in LFP.Although the pores will accommodate a large volume of electrolyte, they serve as a reaction point during the electrolyte decomposition process [11].

The log-log scale of conductivity measurement on LFP/PPy/Clay is shown in Fig. 3. It can be observed that the conductivity pattern could be divided into two regions, that is, an almost frequency-independent region for low- frequency, and the high-frequency region in which conductivity increases in parallel with the increase in frequency. The linear region of conductivity in the lower frequency characterizes the direct conductivity that is a result of the displacement of charge carriers. At low to middle frequency the DC phenomenon of this conductivity found of this measurement, meanwhile at frequency of $40 \mathrm{kHz}$ and higher the conductivity followed AC conductivity phenomenon. Increasing PPy content increases the conductivity of the material obtained. With the addition of clay from 5 to $10 \mathrm{wt} \%$, the DC conductivity of the blends is clearly observed to increase up to three orders of magnitude. The incremental increase in conductivity may be ascribed either to the increase in mobile ion concentration or to the increase of free space allowing the ions to move due to the addition of clay. However, DC conductivity is observed to decrease at the clay concentration of $10 \mathrm{wt} \%$. This decrease may be attributed to the dominating role of ion association over free ion formation, which reduces the number of ions for conduction. Consequently, the longrange drift of ions may be one of the sources of ion conduction in the system's [12].

\section{CONCLUSION}

The main limitation with respect to this compound is its very poor electronic conductivity which limits the 


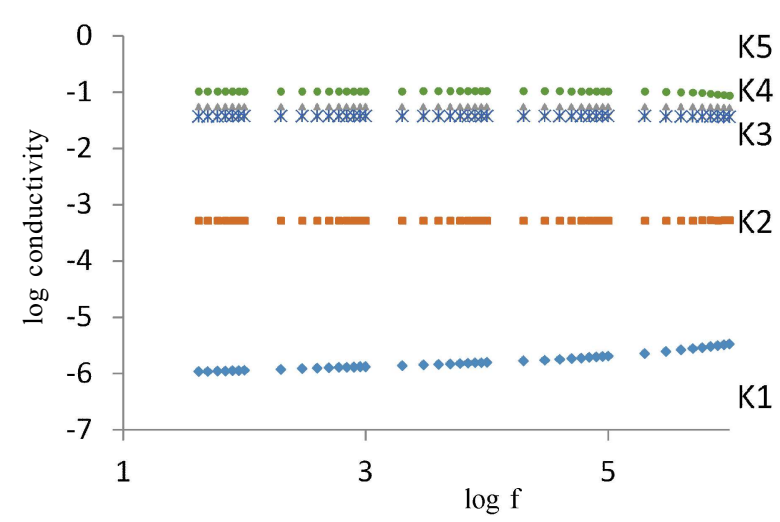

Figure 3. The log-log scale of conductivity measurement on LFP/PPy/Clay.

cycling capability. Several methods have been proposed to solve this problem, such as carbon coating or thin metal particle dispersion. But the amount of carbon recovers the theoretical capacity $(\sim 20 \%)$ and the metal used (copper or silver) is much more expensive than the cathode material itself, therefore in this study cheap clay was added to increase the conductivity of LFP.

The XRD patterns of samples, all the peaks are in accordance with the reference $\mathrm{LiFePO}_{4}$ pattern (PDF No. 40-1499).

The SEM images of composites with different $\mathrm{LiFePO}_{4}$ contents show the provide clear evidence that small crystal particles of $\mathrm{LiFePO}_{4}$ either coat the surface of the clay particles or lie among them.

Increasing PPy content increases the conductivity of the material obtained.

\section{ACKNOWLEDGEMENTS}

We would like to thanks to Dr. Abu Khalid Rivai, as Ka BSBM BATAN to support the research and writing of this scientific paper.

\section{REFFERENCES}

[1] C. Te Hsieh, C. T. Pai, Y. F. Chen, P. Y. Yu, and R. S. Juang, "Electrochemical performance of lithium iron phosphate cathodes at various temperatures," Electrochim. Acta, vol. 115, pp. 96-102, 2014.
[2] G. R. Kiani, S. Boroomand, R. Khodabakhshi, and M. Esmaeili, "A novel co-doped LiFePO $<$ inf $>4<1$ $\inf >/ C$ cathode material, modified for enhanced high power density battery applications," Microelectron. Eng., vol. 136, pp. 77-82, 2015.

[3] H. Shu et al., "Improved electrochemical performance of $\mathrm{LiFePO} 4 / \mathrm{C}$ cathode via $\mathrm{Ni}$ and $\mathrm{Mn}$ co-doping for lithium-ion batteries," J. Power Sources, vol. 237, pp. 149-155, 2013.

[4] I. Gunawan and W. Honggowiranto, "Synthesis and Characterization of LiFePO4/C Composite by Hydrothermal Method," in Proceedings of The International Conference on Materials Science and Technology - ICMST 2014, 2014, pp. 108113.

[5] Z. P. Guo, H. Liu, S. Bewlay, H. K. Liu, and S. X. Dou, "A New Synthetic Method for Preparing LiFePO with Enhanced Electrochemical Performance," J. New Mater. Electrochem. Syst., vol. 6, pp. 259-262, 2003.

[6] Y. P. Liang, C. C. Li, W. J. Chen, and J. T. Lee, "Hydrothermal synthesis of lithium iron phosphate using pyrrole as an efficient reducing agent," Electrochim. Acta, vol. 87, pp. 763-769, 2013.

[7] G. Qin, Q. Ma, and C. Wang, "A porous C/LiFePO/ multiwalled carbon nanotubes cathode material for Lithium ion batteries," Electrochim. Acta, vol. 115, pp. 407-415, 2014.

[8] H. A. N. Chen, S. Han, W. Yu, H. Bo, and C. Fan, "Preparation and electrochemical properties of $\mathrm{LiFePO}_{4} / \mathrm{C}$ composite cathodes for lithium-ion batteries," Bull. Mater. Sci., vol. 29, no. 7, pp. 689692, 2006.

[9] B. Caglar, B. Afsin, A. Tabak, and E. Eren, "Characterization of the cation-exchanged bentonites by XRPD, ATR, DTA/TG analyses and BET measurement," Chem. Eng. J., vol. 149, no. 1-3, pp. 242-248, 2009.

[10] A. Nezamzadeh-Ejhieh and M. Amiri, "CuO supported Clinoptilolite towards solar photocatalytic degradation of p-aminophenol," Powder Technol., vol. 235, pp. 279-288, 2013. 